\title{
Geopolitical Conflicts as a Result of Transformation of the Modern World Order: Reality and Prospects
}

\author{
Ekaterina V. Sidorenko* \\ Siberian Federal University \\ 79 Svobodny, Krasnoyarsk, 660041, Russia
}

Received 15.12.2014, received in revised form 29.01.2015, accepted 29.04.2015

This article explores the current direction of modern geopolitics associated with conflicts of our time. In particular, attention is paid to the analysis of the origins of the aggressive policy of the leading world countries, especially the United States. The authors argue that one of the principal causes of today's regional conflicts that could potentially develop into the world conflicts is the concept of "universal values." The author focuses on the fact that the initiator of such conflicts may be the subjects of globalization. The forcible imposition of such Westernistic standards gives rise to the active rejection in many countries.

The threat of a geopolitical conflict is determined by the transnational information networks uniting the whole world space because ubiquitousness of the extremely intensive mass media and relatively high geographic mobility contribute to the emergence of zones of irrationality.

The line between the internal and interstate conflicts existed for a long period of time, although it was not too severe. With the end of the Cold War this line rapidly began to get blurred: it is the limited conflicts of the internal internationalized nature that have become the main type of the military confrontation in the 90's. At this, the internal internationalized conflicts have combined the most dangerous features of both international and internal conflicts.

When analyzing the causes of geopolitical conflicts of the globalization era we should assume that the interaction of interests on the international scene is often conflicting in nature and it is impossible to remove the conflicts from political practices at all; it is necessary to learn how to manage them minimizing potential costs and damage.

The Western policy of globalization aimed at the destruction of national cultures and practices of globalization in many ways is defined by the subjects of the globalization pressure seeking to impose their own standards to the world community. One of the most dangerous manifestations of the globalization pressure is the policy of "double standards", the display of which is the use of force in international relations and the willingness to apply it in defiance of the international law.

Due to the fact that the world is gradually losing its multipolarity, the globalization methods are becoming more open and aggressive. Fundamentals of stability of the modern system, its viability and activity are declared as derivatives of the state of the American resources, political will and intellect.

At the beginning of the $21^{s t}$ century for the first time in a hundred years foreign countries started talking about the empire and imperial thinking without the usual liberal judgment accepting it as a real fact of political and cultural life.

(C) Siberian Federal University. All rights reserved

* Corresponding author E-mail address: Sidorenko-prof@mail.ru 
The author shows that under the influence of the increasing "neo-Eurasianism" a large place in geopolitical constructions is given to the cultural, civilizational and confessional factors.

Mankind is on the threshold of a qualitatively new and, therefore, unknown period of its development. On the one hand, the nature changing era is ending: the anthropogenic load approached the objective limit and a person begins to solve this problem by adapting himself to the environment. On the other hand, technology is breaking out from the social control, as it was during the transition from feudalism to capitalism carrying not just new social relations, but also a new face of the whole of humanity. Instead of the Westernistic world with dominating parameters of the Western rationalistic civilization, a new civilization is gradually formed on the basis of the organic combination of unity and indivisibility of the world community on the one hand, diversification and pluralism of peoples, cultures and religions, on the other.

Real stability in the international community might be achieved if in solving regional conflicts we take into account the traditions and rely on time-tested international organizations. In this regard, it is important to see the natural aspiration of the peoples for integration as a guarantor of the occurrence of geopolitical conflicts while rejecting all attempts to forcibly impart the system of "Western values" to the peoples because it is fraught with all kinds of conflicts, including the nuclear one.

The article states that when studying a geopolitical meaning of the contemporary conflicts it is necessary to consider that in modern Europe there are conflicts that are absolutely taboo for a "democratic discussion". A range of opinions on the problem is also due to ignorance of the conceptual apparatus of the phenomenon under study and a free addressing with the associated scientific concepts. In other words, the study of the problems of globalism and globalization involves the development of a concerted and recognized concept about their nature and taking into account their free variations in the subsequent interpretation.

Keywords: geopolitical space, regional conflict, forced globalization, mondialism, civilization, subjects of globalization, objects of globalization, geopolitical conflict, globalization world order.

Research area: philosophy.

The threat of a geopolitical conflict is determined by the transnational information networks uniting the whole world space because ubiquitousness of the extremely intensive mass media and relatively high geographic mobility contribute to the emergence of zones of irrationality.

When analyzing the causes of geopolitical conflicts of the globalization era we should assume that the interaction of interests on the international scene is often conflicting in nature and it is impossible to remove the conflicts from political practices at all; it is necessary to learn how to manage them minimizing potential costs and damage.

Globalization challenges are more aggressive in nature, which will inevitably lead to future violent territorial changes, as has already happened in the Balkans, that is, to potential geopolitical conflicts.

Another aspect is fundamentally important: globalization is based on the theory of universal values, which is fraught with negative consequences or problems, many of which are conflicting in nature. As rightly emphasized by many authors, "...the theory of universal values that exaggerates the importance of ideals and standards of living of the individualistic society demonstrates its internal inconsistency" [36]. More and more scientists and politicians come to a disappointing conclusion that "...the idea of a unipolar world that supposedly can overcome chaos and anarchy in the world system not only does not solve the current problems of mankind, but also creates new challenges and ordeals" [4]. 
In a globalizing world, the contrasts are still strong and tend to deepen, and the process itself, the main engine of which is the USA, is Americanized. There are certain contradictions, resistance - in the "core" and at the "periphery". Under the modern conditions Europe is a thinking appendage of the United States, whose geo-political interests and a strategic line are the only and supreme for all the Western powers. Political sovereignty of the European states should also be reduced gradually, and the power passes to a special instance that unites representatives of all the "Atlantic" spaces and is subordinate to the priority rule of the United States [7].

The aggressive policy of the United States relates to the need to maintain a high level of consumption of the citizens. Its lowering will be the beginning of racial, interethnic, interreligious and other conflicts in the United States, so they quite openly use all the resources of the Earth creating the armed forces based on the system of military presence in all resource areas of the world. In terms of ideological preparation of interventions there is a constant "justification" of aggressive actions all over the world as a need to "march for democracy" and "the power implanting of democracy" to the rogue states. Furthermore, they persistently drag Europe into their game that is already lost historically. M. Molchanov rightly emphasizes: "The discourse of globalization developed by advocates of a hyper-liberal economic doctrine can be seen as an attempt of the ideological indoctrination produced by certain groups for their own selfish purposes... The policy held under the slogan of "globalization" or "joining the world market" is nothing else as a "local" culture of the upper groups of the international business-class" [17]. US increasingly act not only as the leading subject of globalization, but also as the main threat to the geopolitical future of humanity.
At the beginning of the 21st century for the first time in a hundred years foreign countries started talking about the empire and imperial thinking without the usual liberal judgment accepting it as a real fact of political and cultural life. Naturally, the more accurate in this context would be the term "superpower", but politically the term "empire" quite accurately expresses the essence of the intentions of the United States as the leading subject of globalization - to ensure their dominance in the world due to the weakening of the world order and the perception of freedom by many countries as anarchy. "In the period of its global dominance America could lay the foundations of a democratic world community, but the temptation of the superpower was stronger than the call of the mind and good. A neo-imperialistic trend in a mondialist variant took over... To unite the international community around the United States on the basis of a grand global universal project (...). Instead, it suggested "the fight against the international terrorism", which will only exacerbate hatred towards America and will increase the terrorist threat" [13].

The new world order is totally inadequate for the era because it does not meet the needs of progress. The fault lies primarily in the United States that, for various farfetched reasons, provokes local wars of different scale and contributes to the development of global opposition of peoples, civilizations and religions. The US actively introduces new forms of transnational exploitation; as a result an absolute majority of the world lives in poverty, or even beyond the poverty line.

It should be noted that America as the embodiment of the technical century with its flat technocentric thinking played a role of the leader in the industrial era. However, in the modern conditions the vanguard role of the US cannot be maintained, since the technocentric approach is 
compromised both as a value and as a way of lifeformation, as well as a human's self-affirmation in the world. According to A. Panarin, "America is now, on the contrary, represents the morally outdated, economically and culturally bankrupt strategies...” [18].

Realizing the disastrous effect of the United States policy, the Western scientists try to "...encourage non-Americans to maintain a critical distance from any kind of claims of what "the American people" or "the American intellectuals" think or do not think and especially encourage them to constantly oppose the ideals of freedom, democracy, human rights and humane social welfare to the current US policy that is so far from these ideals" [15]. There are indications "that in the US trust and public foundations that provided the greatness and the leading position of the country as an industrial power have weakened significantly over the past half-century; <...> Over time society might lose its social capital. There was a time when a developed civil society existed in France, but it was subsequently ruined by an excessively centralized state system" [30]. In addition, the US technological leadership is based on a fairly solid foundation. Their military superiority over any potential competitors is not in doubt, as well as the Washington ability to use force to protect the interests of its country in any part of the globe.

Under the influence of the increasing "neo-Eurasianism" a large place in geopolitical constructions is given to the cultural, civilizational and confessional factors. This model reproduces the "logic of conflict" on the world stage of "the two major powers", which can be traced in the works of Samuel Huntington who predicted a clash of two civilizations - Islamic and liberal. At the same time, the Huntington's concept of "clash of civilizations" is ambiguously evaluated by geopolitists primarily because the majority of today's conflicts take place within certain civilizations; all sorts of "arcs of instability" are built not so much on controversial territories in relation to several civilizations as within the relevant areas. A significant role in the geopolitical studies is taken by new types of conflicts related to the development and dissemination of information, space and other technologies. However, under current conditions, we are witnessing a similar geopolitical conflict. But with the help of a number of theorists this potential conflict is translated into the "antiglobalists" judgment area, i.e. those who do not agree with the statement that "globalization" in its influence prevails over the international law. In their view, the law must adapt to globalization, sacrifice the principles of the state sovereignty, recognize the supremacy of liberal ideology over all others and even disparity of different cultures. That is why Russia faced a dilemma in a globalized world: either to find a way to overcome the irresponsible consumer morality, or to finally sink into the abyss of geopolitical chaos and slippage in the "third world" [37].

Mankind is on the threshold of a qualitatively new and, therefore, unknown period of its development. On the one hand, the nature changing era is ending: the anthropogenic load approached the objective limit and a person begins to solve this problem by adapting himself to the environment. On the other hand, technology is breaking out from the social control, as it was during the transition from feudalism to capitalism carrying not just new social relations on their shoulders, but also a new face of the whole of humanity. Instead of the Westernistic world with dominating parameters of the western rationalistic civilization, a new civilization is gradually formed on the basis of an organic combination of unity and indivisibility of the world community on the one hand, diversification and pluralism of peoples, cultures and religions, on the other. 
Real stability in the international community might be achieved if in solving regional conflicts we take into account the traditions and rely on time-tested international organizations. In this regard, it is important to see the natural aspiration of the peoples for integration as a guarantor of the occurrence of geopolitical conflicts while rejecting all attempts to forcibly impart the system of "Western values" to the peoples because it is fraught with all kinds of conflicts, including the nuclear one.

The line between the internal and interstate conflicts existed for a long period of time, although it was not too severe. With the end of the Cold War this line rapidly began to get blurred: it is the limited conflicts of the internal internationalized nature that have become the main type of the military confrontation in the $90 \mathrm{~s}$. At this, the internal internationalized conflicts have combined the most dangerous features of both international and internal conflicts.

When analyzing the causes of geopolitical conflicts of the globalization era we should assume that the interaction of interests on the international scene is often conflicting in nature and it is impossible to remove the conflicts from political practices at all; it is necessary to learn how to manage them minimizing potential costs and damage [5].

The key actors and carriers of the conflict potential are the states that, basing on their own resources, seek to maximize the control, primarily, the direct military and political control over the territory. At this, the international system remains anarchic and conflicts turn out to be a natural consequence of the collision of the state formations striving for the spatial expansion. The relative "world order" is crystallized in a clash of interests of the major geopolitical actors [25].

The contours of the new world order emerged in the 1990's can be called a system with the only one superpower, but without a formed, uniquely unipolar world. According to S. Huntington, the modern world order is characterized by the presence of one superpower surrounded by several independent centres with much smaller military and economic potential that can not only come into conflict with each other, but also challenge and seriously complicate the life of such a superpower [31].

Up until the final victory of the United States in the Cold War the geopolitical dualism developed into the initially set framework - it was about finding thalassocracy and tellurocracy of the maximum spatial, strategic and power volume.

If the nature of the main geopolitical process of history - the maximum spatial expansion of thalassocracy tellurocracy -is evident for this discipline, then its outcome is uncertain. In this respect, there is no determinism.

Spengler's approach reflects a certain ideological mindset of the era, which has the predominant motifs of exaggeration of just one leading side of the cultural and historical cycle - instability, without any connection with stability and measure, in which these cycles are implemented. From the general theory of dialectics it is known that in case of going out of measure the objects, events, processes lose their qualitative nature, and even go into their dialectical opposite that does not destroy the phenomena completely, but represents a new growth point (bifurcation) of the further historical development [1]. Thus, as noted by M. Delyagin, disappearance of the "force field" of the bipolar confrontation of the socialist and capitalist systems freed only two global civilization initiatives: the Islamic and Chinese [6]. Thereby, M. Delyagin does not agree with the classification of civilizations created by A. Toynbee and even A. Utkin who reveal 34 and 7 civilizations respectively.

Moreover, as we will see below, "conflict capacity" is the most important quality. One of 
the varieties of such conflict is the clash of the Western and Eastern civilizations, which is studied by many scientists in the twentieth century. We believe that such a clash is just a manifestation of the essence of a single civilization" [10].

We can agree with D. Zamyatin who emphasizes that in the evaluation of contemporary problems in the understanding of geopolitics we should take into account that we are talking about the transformation of the old problems into the new ones. It is required to find the laws of functioning and development of meta-geopolitical spaces, their configurations and figurative metageopolitical ensembles. The discovery of these laws is the main condition for the development of modern geopolitics as a theoretical science, applied discipline and a field of project activities [8].

To understand the geopolitical conflict it is important to define the notion of a region. According to S.V. Lurie and L.G. Kazaryan, "a political region is a certain territory allocated by a subjective selection process, arbitrary of the dominant geopolitical force... because in this way it is convenient for it to consider the space of its activity. Thinking patterns are superimposed on reality... In general, a geopolitical project is described as a way of activity of the world forces, a way built only in part on the real reorganization of the region rather than a principle of the space organization" [14].

Geopolitical conflicts that are based on nationalist or religious feelings become much more understandable when viewed as manifestations of striving for recognition, but not rational desires for "utility maximization". Modern liberal democracy is trying to meet this striving by building a political order based on the principle of universal and equal opportunities.

It should be noted that the ideas that in our time are considered as geopolitical emerged at the turn of the $19^{\text {th }}-20^{\text {th }}$ centuries to comprehend the processes of the state expansion and imperialism. Traditional geopolitics considering states as spatial phenomena studied the conditions of growth of their influence, the nature of their interaction with each other. The main factor in the political process was considered as a control over the space, the zone expansion of which ultimately contributes to the growth of the military, economic, demographic and other resource potential of the state. Thus, the power of a state is directly linked to the size and nature of the area it occupies. A state presented itself as a kind of a geographic or spatial-territorial organism having the specific physical and geographical, climatic, resource and other properties and using its own will and interests. It is therefore natural that originally geostrategy was interpreted only as the conquest of a direct control over the territories [28].

The problem of escalation of war conflicts of low intensity into geopolitical conflicts is still relevant both practically and theoretically. Furthermore, its importance is growing because military conflicts began to affect the interests of the leading countries of the world to a much greater extent than, for example, ten years ago. One of the reasons is that not only a nuclear war cannot be a rational means of politics, but also a limited war and even military conflicts cease to reach political goals. Another reason is the formation of a new system of international relations after the collapse of the bipolar security model. The tendency to resolve conflicts and disputes among the states by peaceful political means is strengthening. The international law is gaining recognition of the "force of law" principle, but not "the law of force".

According to V.M. Sergeev, "we see that the view of democracy as a negotiation process significantly changes the understanding of how and under what conditions democracy emerged and in what way a transition to a stable democratic 
system is implemented. I think that the results of the study summarized in this article do not exhaust the possibilities of the "negotiation" approach to democracy. Essentially, the number of questions that need to be answered is significantly increasing with consideration of "standard" problems of the theory of democracy" [24].

Thus, it should be recognized that the globalization practice resulted in a large-scale replacement of basic concepts: a true union of humanity as a common home of the planet on the basis of eternal and universally valid values and the formation of the universal culture turned out to be replaced by building of a totalitarized, UScentred megastructure where ideals and values of a new society and a new human are substituted for pragmatic goals of mass production of an atomhuman who is the most suitable for the nationless, off-the-tradition construction controlled through the manipulation of consciousness. The most convenient way of control becomes a functionhuman of a homogenized type and the average standard who is suggestible and devoid of the established traditions [23].

Profound changes in the geopolitical structures of the world community and transformations of the social and political systems give grounds to speak about the end of a historical period and the entry of the modern world into a qualitatively new stage of its development. The world is becoming more unified, but not safer. The regional and local conflicts that are traditional for the world history tend to potentially escalate into geopolitical conflicts. The peculiarity of the present stage is not only in the fact that the era of post-industrialism is replaced by the information era, but also in that the process of change has affected the economic, political, socio-cultural and spiritual spheres. A stage of forming of a new type of the world community is beginning. The most visible manifestation and indicator of these processes and phenomena is globalization.
In the context of globalization it is rightful to speak about strengthening the desire for regionalization in the modern world. Otherwise, such a desire can be called regionalism. According to G.K. Shirokov and A.I. Salitsky, it is “... a quite natural and rational reaction to the excessiveness of external influences, the imbalance of the world economy and the growing hegemonism in the world politics" [33]. In any case, with all the contradictory positions, it must be noted that the facts and the events of recent years show that the planet is rapidly going through a process of becoming a single global society. Regarding globalization V.S. Styopin writes: "the modern civilization is at a critical stage of its development. Even today, we can see the outlines of a completely new human world that is being formed in the contradictions and tensions of our era. The occurring changes are so fundamental that the Western philosophers, sociologists and futurologists with good reason compare them with the transition of society from the Stone Age to the Iron Age" [26].

The understanding of a single humanity does not fit a concept of so-called local civilizations. In particular, in a book titled "The Decline of Europe" O. Spengler asserted that humanity is an empty word, and that it should be excluded from the range of problems of historical forms. A British historian Arnold Toynbee thought in the same spirit. In his opinion, there is no Humanity, but there is some independent cultural and historical systems ("civilizations") emerging, forming, developing and dying like biological organisms [28].

From our point of view a conflict-free future in the field of geopolitics also implies the understanding that building of a new geopolitical reality in the context of globalization can only be based on the dialectical approach to the current realities both between the states and within a particular society. Obviously, referring to this 
particular set of problems A. Panarin wrote: "The old truths about fair and unfair wars must be taken into account if, of course, we are not utopians once again waiting for the paradise on earth and a world piece without wars. The paradox is that the most terrible and destructive wars occur following penetration of another pacifist utopia into the consciousness... Aggressors both internal and external, those who decided to expropriate a foreign territory and those who decided to expropriate property belonging to the people - represent a decomposition side" [19].

Ultimately, prevention of geopolitical conflicts depends largely on the ability to find a way of reconciling two opposing tendencies that are characteristic of the modern civilization primitively egoistic, consumer and cosmic, as well as the two types of society based on them: individualist and collectivist. It is not by accident that today many serious scientists talk about the need for the consent philosophy like a certain guarantee to prevent geopolitical conflicts.

The transformation of ideas about the state is of fundamental importance in preventing the geopolitical crises in the future. According to $\mathrm{T}$. Verkhovtseva in a rationalist version of social philosophy a society, a state is represented as the formation artificially created by human beings, their consciousness and will. A degree of optimality of such an artificial structure allegedly depends on how human nature is apprehended and how adequate the adopted and implemented community project is to it. The essences cognized by philosophy appear in this case as a norm, sample and ideal for the empirical reality. The element of utopianism becomes inevitable, which is essentially unhistorical, since the right public order that is relevant to the essence does not imply the history of its formation, but can be set up anywhere anytime. Overcoming this contradiction is possible when distinguishing between types of society (individualist and collectivist) and corresponding ideals of the social life [3].

The current situation "...indicates not the emergence of a "single world", but the growing civilizational confrontation, which clearly formed two poles... We declare that the modern world is not globalized, and the only problem that has a global nature is the interaction between the "first" world and all others, i.e. between the democratic post-industrial civilization and the traditional social systems that have not yet formed a true civil society" [9]. In addition, "the modern daily routine led people to a situation, which was studied by E.V. Ilyenkov ("Cosmology of the spirit") in his mental experiment, where a person had to take care of the preservation and extension of life. Being that is a guarantor of the human emergence and existence turns out to be in danger. There comes a true role of thinking helping the world process, its "actual cycling" as the "true infinity". The current practice of the global crisis creates other approaches. The question is formulated not from the standpoint of a thinking substance as the highest form of its motion able to sacrifice itself, but rather from the standpoint of a higher egoistic subject ready to sacrifice the very nature capable of developing intelligent beings. As a result of the nature sacrifice "technology" wins. A human turns out to be on a side of destruction and extermination of being, instead of contributing to the development of being" [21].

Along with the traditional geopolitical concepts of sustainable development we also observe the elements of universality and generality that, in our opinion, reflect precisely the dialectical tradition of understanding of the world. "The main criterion for identifying a social centre of the Universe is the highest stage of the development of matter. Only a human meets this criterion. Without human activity the Universe is "fatuous". Therefore, humanity is obliged to sort out the surrounding universe as its own 
natural foundation. People are deeply indebted to nature. Universality is a new level of thinking of earthlings as a single global civilization. The global civilization is the basis for the manifestation of its universality. Therefore, the resolution of global problems is a prologue to reflect on the universal needs" [22].

The essence of Russian cosmism does not lie in the development of extraterrestrial spaces, knowledge of extraterrestrial civilizations, but the problems of introducing a new science project. Lt us note that the phenomenon of Russian cosmism as a forerunner of the new science project is natural. It is anticipated by the basis of the collectivist method of production of social life, conciliar spirituality of the Slavs, collectivist foundations of statehood, etc. known from the pagan times and the Byzantine traditions [32].

The global problems, first of all a problem of war and peace, can indeed be a source of irreversible changes that are dangerous for the existence of mankind. However, these problems are basically solvable. Many scientists confidently state that "...suicide of civilization is not inevitable" [11]. "Illusions of the end of the second millennium have dissipated, and with the beginning of the third millennium opens a new historical era, still unclear and incomprehensible. The history of globalization and the globalization of history develop into an epilogue that has a lot more questions than answers" [27]. But the main thing is that the space, dialectical, information science project is currently establishing in the field of scientific knowledge more and more firmly. It is not making its way by imposing itself by someone to the scientific community. On the contrary, together with the deployment of crisis of the modern civilization, it appears as a real way to resolve the crisis, the way in which the scientists can find productive scientific results indicating the azimuth of the salvation of mankind, the azimuth of resolution of the global problems.
In a recent article "Asymmetric Future" A.V. Yurkevich raises with a new force the old question of the future diversity, its dependence on our actions and our ideas about it. Noting the extremely poor fulfilment of predictions made in the 70 's of the $20^{\text {th }}$ century regarding our time, the author writes that "we, having lived up to the new millennium, turned out to be not in the future we expected. But there is another possibility that consists in the fact that having different options for its development the humanity chose not the right option that seemed to be most likely, meaning that, in a sense, it is not the predictions that turned out to be wrong, but the mankind is developing in the "wrong" way" [35].

Choosing the preferred path for the development of humanity as a whole or some part of it requires the analysis of all possible alternatives and the Socratic question in each of them. Meanwhile, the positions of the most prominent researchers of the globalization and post-industrial transformation challenges give cause for concern of the loss of the critical spirit, the acceptance of a certain path as the only possible, or, at least, the only desirable one [34].

The contemporary world globalization processes support the view of A.S. Panarin who noted that "the philosophy of history has a dilemma:

- either this or that global historical concept promises a guaranteed history - at the cost of the exclusion of alternatives, hence the freedom of historical choice replaced by the "immutable laws";

- or it opens available alternatives and, thus, our freedom to go in one direction or another, but at the risk of dramatic errors, contradictions and failures" [20].

Modern scientists now understand that a human becomes not only a geological factor, but also a cosmic one. In this regard, the implementation of the humanistic principle as 
the main one in its classical expression becomes dangerous for the existence of humanity [29]. An important argument in favour of the necessity of the geopolitical outlook of the future is a fair point made by the academician N. Moiseev: "the analysis of the current structure of contradictions, their study from the perspective of the possibilities of the existence of collective decisions will lead to the emergence of new social studies sections aimed at the study of the spectrum of organizational social structures capable of providing of co-evolution of nature and society, in other words, providing of the transition of mankind into the era of the noosphere" [16].

Thus, many of today's conflicts are determined by the transformation of the modern geopolitical space, which is a consequence of violent globalization. In the upcoming era responsibility for the control and resolution of regional conflicts should be attributed to the leading states of those civilizations that are dominant in the region.

\section{References}

1. Andreeva, O.A. Stabilnost $i$ nestabilnost $v$ kontekste sotsiokulturnogo razvitiya [Stability and instability in the context of socio-cultural development]. Taganrog: TIME, 2000. $178 \mathrm{p}$.

2. Buchanan, P.J. Smert Zapada [Death of the West]. SPb: Terr Fantastica, 2003. P. 329-330.

3. Churinov, N.M. Sovershenstvo i svoboda [The perfection and freedom]. Philosophical Essays. Krasnoyarsk, 2003. P. 60.

4. Delyagin, M.G. Mirovoi krizis: Obshchaya teoriya globalizatsii [The World Crisis: The General Theory of Globalization]. M: INFRA-M, 2003. P. 332.

5. Dugin, A.G. Osnovy geopolitiki. Geopoliticheskoe budushcheye Rossii [Basics of geopolitics. The geopolitical future of Russia]. M: “Arctogaea”, 1997. P. 65.

6. Fenvesh, T.A. Dva printsipa sotsialnosti [Two principles of sociality]. Theory and history. 2003. № 3. P. 82.

7. Fukuyama, F. Doveriye. Sotsialnye dobrodeteli $i$ sozidanie blagosostoyaniya [Trust. Social virtues and the creation of well-being (excerpts from the book)] A new, post-industrial Wave in the West, ed. By V.L. Inozemtsev. M: Academia, 1999. P. 198.

8. Huntington, S. Stolknovenie tsivilizatsiy i preobrazovanie mirovogo poryadka [The clash of civilizations and remaking of the world order] A new, post-industrial Wave in the West, ed. By V.L. Inozemtsev. M: Academia, 1999. P. 532.

9. Inozemtsev, V.L., Kuznetsova, E.S. Glovalniy konflikt XXI v. Razmyshleniya ob istokakh $i$ perspektivakh mezhtsivilizatsionnykh protivorechiy [The global conflict of the $21^{\text {st }}$ century. Reflections on the origins and prospects of inter-civilizational contradictions] Polis. 2001. № 6. P. 131-132.

10. Isaev, V.D. Chelovek v prostranstve tsivilizatsii i kultury [A human in the space of civilization and culture]. Lugansk: Svitlytsya, 2003. Pp. 21-25.

11. Kazyutinsky, V.V. Nookosmologiya i globalnye problemy [Noocosmology and global problems] Philosophy and sociology of science and technology. Yearbook 1988-1989. M: Nauka, 1989. P. 89.

12. Kosolapov, N.A. O meste geopolitiki v epokhu globalizatsii [On the place of geopolitics in the era of globalization] East (Oriens). 2003. № 4. P. 150.

13. Kudashev, V.I. Krizis politiki v protsesse globalizatsii i lokalizatsii [A crisis of politics in the process of globalization and localization]. Theory and History. 2004. № 3. P. 174. 
14. Lurie, S.V., Kazaryan, L.G. Printsipy organizatsii geopoliticheskogo porstranstva (vvedeniye $v$ problemu na primere Vostochnogo voprosa) [Principles of organization of the geopolitical space (introduction to the problem on the example of the Eastern problem)]. Social studies and modernity. 1994. № 4. P. 94, 95.

15. McBride, W. Globalizatsiya $i$ mezhkulturniy dialog [Globalization and the intercultural dialogue] Problems of Philosophy. 2003. № 1. P. 87

16. Moiseev, N.N. Opravdaniye edinstva (kommentarii k ucheniyu o noosfere) [Justification of unity (comments to the study of the noosphere)] Philosophy and Sociology of Science and Technology. Yearbook 1988-1989. M: “Science”, 1989. P. 111.

17. Molchanov, M. Istoki rossiyskogo krizisa: globalizatsiya ili vnutrenniye problemy? [The origins of the Russian crisis: globalization or internal problems?] M. Molchanov. Polis. 1999. № 3. P. 98.

18. Panarin, A.S. "Konets liberalnoy epokhi" ili kulturotsentrism kak postindustrialnaya sotsiokulturnaya "faza retro"? ["The end of the liberal era" or culture-centrism as a post-industrial, socio-cultural "retro phase"?] Civilizational model of international relations and its implication: scientific discussion edited by "Polis". Polis. 1994. № 1. P. 40.

19. Panarin, A.S. Strategicheskaya nestabilnost XXI veka [Strategic instability of the $21 \mathrm{st}$ century] Moscow. 2002. № 4. P. 97.

20. Panarin, A.S. Filosofiya istorii [The philosophy of history]. M: "Gardariki”, 1999. P.

21. Prokhorov, M.M. Paradoksy deyatelnosti [Paradoxes of activity]. Bulletin of the Philosophical Society. 2003. № 1. P. 124.

22. Pyrin, A.G. Vselenskost [Ecumenicality]. Bulletin of the Philosophical Society. 2003. № 1. P. 140.

23. Samokhvalova, V.I. Proekt globalizatsii i metafizicheskiy megaproekt cheloveka [The project of globalization and the human metaphysical megaproject]. Philosophical Sciences. 2003. № 3. P. 114.

24. Sergeev, V.M. Demokratiya kak peregovorniy protsess [Democracy as a negotiation process]. M: Prometheus-Yurayt-M, 1999. P. 309.

25. Shirokov, G.K., Salitsky, A.I. Globalizatsiya i/ili regionalizatsiya [Globalization and/or regionalization] East (Oriens). 2003. № 5. P. 85.

26. Shuper, V.A. Rossiya v globalizirovannom mire: alternativy razvitiya [Russia in the globalized world: alternative development] Problems of Philosophy. 2008. № 12. P. 3.

27. Solovyov, E.G. Geopoliticheskiy analiz mezhdunarodnykh problem sovremennosti: Pro et contra [Geopolitical analysis of international issues of our time: Pro et contra]. Polis. 2001. № 6 . P. 118.

28. Stepin, V.S. Epokha peremen i stsenarii budushchego [The era of changes and scenarios for the future]. [Electronic resource]. http://www.philosophy.ru

29. Strada, V. Globalizatsiya i itsoriya [Globalization and History]. Modern and Contemporary History. 2002. № 6. P. 61.

30. Toynbee, A.J. Postizheniye istorii [Comprehension of History]. M: Progress, 1991.

31. Verkhovtseva, T.E. Sobornost: russkaya traditsiya i russkiy ideal [Conciliarism: Russian tradition and Russian ideal] Theory and History. 2004. № 3. P. 86. 
32. Volodin, A.G., Shirokov G.K. Globalizatsiya: istoki, tendentsii, perspektivy [Globalization: origins, trends and prospects]. Polis. 1999. № 5. P. 257. 2.

33. Vostrikov, S.V. Uregulirovaniye konfliktov $v$ blizhnem zarubezhie: $k$ razrabotke strategii Rossii [The settlement of conflicts in the neighboring countries: towards a strategy of Russia] Polis. 1999. № 5. P. 115.

34. Yurkievich, A.V. Assimetricheskoe budushchee [Asymmetric future]. Problems of Philosophy. 2008. № 7. P. 78-89.

35. Yatsenko, M.P. Globalizatsiya kak forma istoricheskogo protsessa $i$ aksiologiya istorii [Globalization as a form of the historical process and axiology of history] Scientific problems of the Humanities research. Scientific and theoretical journal. Issue 9. Pyatigorsk, 2010. P. 230.

36. Yatsenko, M.P., Malinin, A.V. Problemy sovershenstva v kontseptsiyakh russkogo kosmizma [The problem of perfection in the concepts of Russian cosmism]. Scientific Opinion: Scientific Journal. $\mathrm{SPb}, 2012$. № 12. P. 22. 11.

37. Zamyatin, D.N. Geopolitika: osnovnye problem i itogi razvitiya v 20 v. [Geopolitics: the main issues and results of the development in the twentieth century]. Polis. 2001. № 6. P. 112-113.

\title{
Геополитические конфликты как результат трансформации современного мироустройства: реальность и перспективы
}

\author{
Е.В. Сидоренко \\ Сибирский федеральный университет \\ Россия, 660041, Красноярск, пр. Свободный, 79
}

В данной статье исследуется актуальное направление современной геополитики, связанное с конфликтами современности. B частности, в статье уделено внимание анализу истоков агрессивной политики ведущуих мировых стран, в особенности США. Авторами доказывается, что одной из принципиальных причин возникновения современных региональных конфликтов, которые могут потенцииально перерасти в мировые, является концепция «общечеловеческих изенностей». Автор акцентируют внимание на том факте, что носителем подобных конфликтов могут выступать субъекты глобализации. Насильственное навязывание подобных вестернистских образиов вызывает активное неприятие во многих странах мира.

Угроза геополитического конфликта детерминирована транснациональными информационными сетями, объединяющими все мировое пространство, потому что повсеместное распространение чрезвычайно емких средств массовой информации и сравнительно высокая географическая мобильность способствуют возникновению зон иррациональности.

На протяжении продолжительного периода грань между внутренними и межгосударственными конфликтами существовала, хотя и не была слишком жесткой. С окончанием холодной войны сама эта грань начала стремительно размываться: именно ограниченные конфликть внутреннего интернационализированного характера стали основным типом вооруженного противостояния в 90-х годах. При этом внутренние интернационализированные конфликты объединили в себе наиболее опаснье черты как международных, так и внутригосударственных конфликтов. 
В анализе причин геополитических конфликтов эпохи глобализации следует исходить из того, что взаимодействие интересов на международной арене уже само по себе зачастую носит конфликтный характер, что нельзя устранить конфликты из политической практики вообще; нужно научиться управлять ними, минимизируя возможные издержки и ущерб.

Политика глобализации, проводимая Западом, направлена на уничтожение национальных культур, и методы глобализации во многом задаются субъектами глобализационного давления, стремящчимися навязать свои стандарты всему мировому сообществу. Одно из самых опасных проявлений глобализационного давления - это политика «двойных стандартов», проявлением которой является использование силь в международных отношениях и готовность ее применять вопреки международному праву.

В связи с тем что мир постепенно теряет свою многополярность, глобализационные методы становятся все более откровенными и агрессивными. Основы стабильности современной системы, ее жизнеспособность и деятельность объявляются производными от состояния американских ресурсов, политической воли и интеллекта.

В начале XXI века впервые за сто лет за океаном заговорили об империи и имперском мышлении без привычного либерального осуждения, приняв это как реальный факт политической и культурной жизни.

Автор показывает, что под влиянием набирающего силу «неоевразийства» в геополитических построениях большое место отводится культурно-цивилизационным и конфессиональным факторам.

Человечество стоит на пороге качественно нового и потому неведомого периода своего развития. С одной сторонь, заканчивается эпоха изменения природы: антропогенная нагрузка приблизилась к объективному пределу, и человек начинает решать эту проблему путем приспособления себя к окружающей среде. С другой - технологии вырвутся изпод общественного контроля, как это было при переходе от феодализма к капитализму, неся на плечах уже не просто новые общественные отношения, но и новый облик всего человечества. Вместо вестернистского мира, в котором доминирующие позиции занимают основополагающие параметры западной рационалистической циивилизации, постепенно формируется новая цивилизация на началах органического сочетания единства и неделимости мирового сообщества, с одной стороны, диверсификации и плюрализма народов, культур, религий-с другой.

Реальной стабильности в мировом сообществе можно достичь, если в решении локальнорегиональных конфликтов учитывать традиции и опираться на проверенные временем международные организации. В данной связи важно воспринимать естественное стремление народов к интеграции как гарант от возникновения геополитических конфликтов, отвергая при этом всяческие попьтки насильственной прививки народам системьл «западных цченностей», поскольку это чревато всеми видами конфликтов, включая ядерный.

В статье доказывается, что при исследовании геополитического смысла конфликтов современности необходимо учитывать, что в современной Европе существуют абсолютно табуированные темы для «демократического обсуждения». Разброс мнений по рассматриваемой проблеме объясняется также игнорированием понятийного аппарата изучаемого явления, вольным обращчением с относящимися к нему научными понятиями. Иными словами, исследование проблем глобализма и глобализации предполагает разработку согласованного и признанного понятия об их сущзности и учет вольных интерпретаций в последующем толковании.

Ключевые слова: геополитическое пространство, региональный конфликт, насильственная глобализация, мондиализм, цчивилизация, субъекты глобализации, объекть глобализации, геополитический конфликт, глобализациионное мироустройство.

Научная спеииальность: 09.00.00 - философские науки. 